7 Ekers D, Godfrey C, Gilbody S, Parrott S, Richards DA, Hammond D, et al. Cost utility of behavioural activation delivered by the non-specialist. Br J Psychiatry 2011; 199: 510-1.

8 Manos RC, Kanter JW, Busch AM. A critical review of assessment strategies to measure the behavioural activation model of depression. Clin Psychol Rev 2010; 30: 547-61.
9 Dichter GS, Felder JN, Petty C, Bizzell J, Ernst M, Smoski MJ. The effects of psychotherapy on neural responses to rewards in major depression. Biol Psychiatry 2009; 66: 886-97.

10 Rusch LC, Kanter JW, Brondino MJ, Weeks CE, Bowe WM. Biomedical stigma reduction programs produce negative but transient effects on a depressed low-income community sample. J Soc Clin Psychol 2010; 29: 1021-31.

\section{poems \\ by doctors}

\title{
Why Did You Become a Doctor?
}

\section{Miles Burrows}

\author{
I originally wanted to be a witch \\ Sitting inside a Leiden jar \\ In the pathology museum \\ Or manifesting suddenly in a wardrobe \\ Or a trick of the light in a motorway café.
}

My fallback application

Was to become one of those nuns in La Dolce Vita

In an enormous starched wimple

Like the collar of Phillip II

As if my head was something that had fallen into a serviette.

I wanted to be Dr Zhivago

And have a Russian mistress on a sledge.

There are no crosswords in heaven

Because there is no tomorrow for the answer.

Later, psychiatry took my fancy.

I wanted to rescue an enchanted mad princess

From a tower in a wood

Where the senior registrar was making curry.

I hoped to meet some brilliant eccentric

Cataloguing shadows, or decanting clouds like Harpic

Into old sherry bottles.

The works of Freud were like a prolonged

Businessman's lunch in a German restaurant

Where the waiters have aprons that reach down to their ankles

And there is only one course on the menu but it is very good.

| was looking for an Irish country hour, Grade || listed,

Set in parkland, where the Medical Director

Organised an annual rough shooting party

For the staff to take potshots at each other

From behind hayricks

While inside the building huge women sat in stone circles

And we taunted them like boys taunting a dolmen.

Or the Persian king whipping the sea.

Sitting in the water tower on night duty

Waiting for the arrival of the princess

I found further philosophers plied their antique charms.

Minswanger, Glogg, Jaspers,

Kleist, Heidegger, Snoek

opened their swing doors to me

Like bistros in Charlotte Street with irresistible names.

And I would conjure with their smoky names

Savouring their names like baroque Italian ice creams

Or like a harpsichordist

Who slowly releases his fingers from the keys

And looks up at the candlelit ceiling

As if the music were someone he had left behind.

This poem is from The Hippocates Prize 2010: The Winning and Commended Poems, published by The Edge Press.

Chosen by Femi Oyebode. 